tigaciones más rigurosas que en materia histórica o científica ha conocido nuestro país. Si todo el libro estuvo presidido por la responsabilidad, esta última parte alcanza los caracteres de una suprema ciencia. La refutación a Salvador de Madariaga - cuya biografía queda a considerable distancia por debajo de la que comentamos-; el estudio del plan de Colón para el viaje por vía marítima; la exposición de la cultura de Colón, etc., son razones eminentes del saber alcanzado por Alvarez Pedroso en la materia. Estamos en presencia de una obra que marcará época en la cultura cubana. Y si llegamos a esta afirmación, que podrá parecer hiperbólica a los escépticos de siempre, es porque tenemos en cuenta no sólo el aporte gigantesco de datos, sino la presencia de un método, de una paciente investigación. Método, investigación rigurosa, calma, que por ser las antítesis de nuestra frecuente ausencia de método, apresuramiento y empleo de materiales resobados, ofrecen una altísima lección. En un medio propicio al trabajo cómodo, a la festinación, a la irresponsabilidad, ha hecho su aparición una obra -y se recordará cuánto insistió Unamuno en la diferencia entre "libro" y "obra"- que nos honra de modo insuperable. Esta es la Obra Bien Hecha, la Obra nacida del saber genuino, del amor, de la generosa devoción.

No acertamos sino a recomendarla a nuestros lectores. No conocemos a su autor, no sabemos do él sino que ha escrito esta monumental prueba de inteligencia. $\mathrm{Y}$ como es afán nuestro, vivir en atención a pruebas semejantes, sobre todo cuando llevan el cuño nuestro, cuando son nacidas en la patria nuestra, insistimos ante cada lector, ante cada amigo lejano o inmediato, para que no deje pasar en silencio, en olvido, en abandono, esta fiesta del saber y la honestidad intelectual - este fruto de responsabilidad y sabor amoroso.

\title{
Gastón Baquero,
} La Habana.

Pablo H. Vela Eguez, El árbol que canta.-Quito, Imp. del Ministerio de Educación, 1943.

Las poesías de Vela Eguez renuevan una tendencia que en los últimos tiempos ha sido tenida en poco. En medio de las modernas voces poéticas y de las exóticas combinaciones estróficas, es deleitoso hojear una obra 
como El árbol que canta, cuyos versos aprisionan ideas de alto sentido filosófico y se someten a los antiguos postulados de la métrica.

En la primera parte de El árbol que canta hay vida y belleza. En la tierra morena hunde el árbol las raíces de su existencia, y ella le ofrece zumos nutricios, caricia materna y dón de producción. El árbol que eleva su estructura con tendencias al infinito, va extendiendo sus ramas y sus ansias; tal el espíritu del poeta que, con tener las raíces hundidas en el regazo maternal, encumbra sus anhelos en busca de las eternas vivencias, y canta así todas las emociones que la vida encierra: el amor de la esposa, cristalizado en sus manos que acarician; el cielo, el agua, el sol, la paternidad, la patria. Su emoción poética es indiscutible, aunque a veces su verso no está labrado con el aliño y el cuidado que aquélla necesita para lograr su perfecta expresión.

La segunda parte del libro tiene por título: "Tabernáculo bolivariano". La figura del padre de estas nacionalidades - cuya presencia es cada día más fuerte entre nosotros y cuya memoria es más necesaria a cada hora, cuando las naciones bolivarianas tienden a perder la configuración no ya sólo espiritual sino jurídica que el padre y creador de ellas les otorgó con magnífica mano y con visión de genio - no podía faltar en la emoción poética de un cantor bolivariano. Quizás es la parte de la obra que más aliento ofrece, que más emoción estética encierra, que más atrevidas figuras acendra, que más altiva expresión artística tiene.

En la tercera parte, Vela Eguez nos of rece otra gama de su emoción lírica, templada por el anhelo de amistad hacia otros pueblos.

El árbol que canta viene a enriquecer la vasta producción poética ecuatoriana, que tantos triunfos ha alcanzado.

\section{Carlos Betancur Artas, Medellin.}

Juan LarRea, El surrealismo entre Viejo y Nuevo Mundo.-México, Ediciones "Cuadernos Americanos", 1944.

"Algo más que literatura" aspira a ser el surrealismo, según afirma Juan Larrea; y a desentrañar este "algo más" o, si se quiere, este "más allá", se aplican ahora los afanes del singular poeta que tan reciamente siente el destino de nuestro Continente. "Algo más que poeta" llamaríamos 